\title{
MRA agreement signals start of global harmonization
}

After years of procrastination and months of compromise (Nature Biotechnology 15:119-120, 1997), the European Commission (EC; Brussels) and the US Food and Drug Administration (FDA; Rockville, MD) seem to have finalized a Mutual Recognition Agreement (MRA) on pharmaceutical products and site inspections. However, the agreement depends on three more years of compromise and indecision.

Inspections of pharmaceutical (including biotechnological) production sites by drug authorities can be an expensive and timeconsuming process for authorities and manufacturers alike. At present, all drugs in the US must be produced at factories that FDA inspectors have approved. In Europe, as part of the move to create a single market, there is now mutual recognition of national inspections throughout the European Union (EU; Brussels). The US-EU MRA discussions over the last three years have been an attempt to extend mutual recognition.

MRAs in six areas of trade- of which pharmaceuticals is one-have received political attention at the highest level in both the US and Europe. During his visit to Europe at the end of May, after he had met European Commission President Jacques Santer, US President Bill Clinton said that the MRA talks had achieved "a breakthrough" that he hoped would "lead to an agreement within a few days." However, similarly optimistic sentiments had been expressed by Santer and Clinton at their last summit meeting in the United States in November. The expectation then was that the text of a pharmaceutical agreement would be ready by the end of January of this year.

Some believe that things will move ahead this time. Andrew Dickson, secretary-general of the European biotechnology umbrella group, EuropaBio (Brussels) says "The political will is now out there. . . Officials have been sent to work things out."

One of the issues that had stalled the discussions previously was the FDA's discomfort with full mutual recognition of inspections carried out by regulators in all the European member states. Their concern, never officially stated, of course, was that while authorities in countries like the UK and Germany had comparable competences to those of the FDA, authorities in some of the southern
European nations might not. That hurdle has been overcome by the adoption of a "transitional period" of three years, after which the FDA and the EC will draw up a list of the authorities that provide "appropriate" or "equivalent" levels of competence and that can, therefore, be included under the MRA.

During that transitional period, according to Philippe Meyer, of the pharmaceutical unit of the EC's industry directorate, DGIII, there will be joint inspections-from different European nations - within Europe in an attempt to try to raise standards to a uniform level. The FDA has requested the option to participate in those inspections, but the expectation is that it will not exercise that option very frequently.

The US-EU agreement does not go as far as that between the EU and Canada, the text of which was completed and agreed to just a week before the US-EU agreement. But Meyer, for one, is satisfied that the EU-US MRA goes just about as far as it could. "It is much more binding and much more predictable that any of the agreements between the US and individual European member states," he says

\section{...optimize your PCR in one run!}

The gradient function of the new Mastercycler gradient enables rapid testing of 12 different temperatures in one experiment.

$\begin{array}{lllllllllllllll}1 & 2 & 3 & 4 & 5 & 6 & 7 & 8 & 9 & 10 & 11 & 12 & 13 & 14\end{array}$

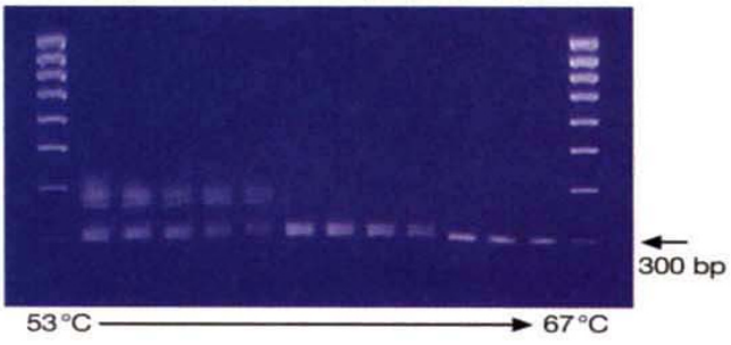

Fig. 1: Experimental determination of optimal annealing temperature: The calculated primer annealing temperature was $56.5^{\circ} \mathrm{C}$, the actual annealing temperature is $63.5^{\circ} \mathrm{C}$. The ribosoma spacer region of mycoplasms from $\mathrm{H} 9$ cell cultures was amplified.
Using the gradient function of the universal block, a gradient of 53 to $67^{\circ} \mathrm{C}$ was set. The following test parameters were selected: denaturation $10 \mathrm{~s}$, annealing $15 \mathrm{~s}$, elongation $20 \mathrm{~s}$, amount of Taq-polymerase 0.75 units; duration of entire experiment: $<1 \mathrm{~h}$.

$\begin{array}{llllllllllllll}1 & 2 & 3 & 4 & 5 & 6 & 7 & 8 & 9 & 10 & 11 & 12 & 13 & 14\end{array}$

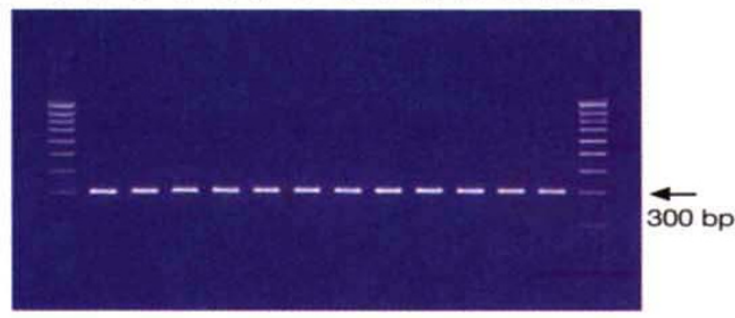

Fig. 2: Amplification shown in fig. 1 performed under optimized temperature conditions. In this experiment, the universal block was set to a uniform temperature in the annealing phase. The outstanding temperature homogeneity of the block guarantees reproducible PCR results.

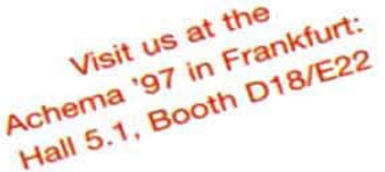

\section{eppendorf}

Eppendorf-Netheler-Hinz GmbH · 22331 Hamburg · Germany - Tel. +49 (40) 538 01-0 - Fax +49 (40) $53801-556$ e-mail: eppendorf@eppendorf.com · eppendorf home page: http://www.eppendorf.com 